\title{
Goal Structures and Teachers' Sense of Efficacy: Their Relation and Association to Teaching Experience and Academic Level
}

\author{
Christopher A. Wolters and Stacy G. Daugherty \\ University of Houston
}

\begin{abstract}
Goal structures reflect the motivational beliefs promoted by the prevailing instructional policies and procedures within an academic setting. Teachers' sense of efficacy refers to individuals' judgments or beliefs regarding their ability to accomplish critical instructional tasks. The relation between these constructs and differences on the basis of teaching experience and academic level were investigated. Teachers $(N=1,024)$ completed a self-report instrument via the Internet. Results indicated that teachers' sense of efficacy could be used to explain the classroom mastery goal structure they reported. Also, some aspects of teachers' sense of efficacy were greater for those with more teaching experience, whereas differences in goal structures were associated with academic level. Findings are discussed with regard to their implications for both theory and teacher training.
\end{abstract}

Keywords: academic level, goal structure, motivation, teacher experience, teachers' sense of efficacy

At a broad level, motivational research focuses on explaining behavioral outcomes, such as choice, effort, and persistence (Graham \& Weiner, 1996). Within educational contexts, much of this research has focused on individual differences in students' achievement motivation through an evaluation of their beliefs, attitudes, values, perceptions, and similar cognitive constructs (Pintrich \& Schunk, 2002). Various models have been developed to explain individual differences in motivation and to understand the effect of those differences on students' behavior, learning, and academic achievement. To a lesser extent, models focused on motivationally relevant processes related to the classroom climate and teacher also have been developed for academic settings. In the present study, we extended the work investigating the relation between classroom goal structures and teachers' sense of efficacy, as well as differences in these constructs on the basis of teaching experience and academic level.

\section{Achievement Goal Theory and Classroom Goal Structures}

Goal structures are defined as the prevailing instructional policies and procedures within an academic setting, such as a classroom or school (Ames \& Archer, 1988; Kaplan, Middleton, Urdan, \& Midgley, 2002; Urdan, 1997; Wolters, 2004). Following earlier views of achievement goal theory, two goal structures have been emphasized. A mastery structure describes an academic context that tends to foster students' adoption of mastery goals. A performance structure is a context in which the practices, policies, and

Christopher A. Wolters and Stacy G. Daugherty, Department of Educational Psychology, University of Houston.

Stacy G. Daugherty is now at the Galena Park Independent School District, Galena Park, Texas.

Correspondence concerning this article should be addressed to Christopher A. Wolters, College of Education, Department of Educational Psychology, 491 Farish Hall, Houston, TX 77204-5029. E-mail: cwolters@uh.edu procedures foster students' adoption of performance goals. As with goal orientations, it may be that goal structures should also be differentiated on the basis of whether they foster approach or avoidance goals (Church, Elliot, \& Gable, 2001). However, this theoretical distinction has yet to be supported with strong empirical evidence (Wolters, 2004). The present study incorporated a measure of mastery structure and a performance approach structure but not a performance avoidance structure.

Goal structures are viewed as critical constructs because of their impact on students' motivation and achievement. Research has shown that the prevailing goal structure in a classroom or school is related to students' personal motivational beliefs. For instance, several studies have found that a mastery structure, but not a performance structure, was associated with higher levels of students' self-efficacy for learning (E. Anderman \& Young, 1994; Kaplan \& Maehr, 1999; Roeser, Midgley, \& Urdan, 1996). Goal structures also have been tied to the personal goal orientations that students adopt (E. Anderman \& Midgley, 1997; E. Anderman \& Young, 1994; Kaplan \& Maehr, 1999; Midgley \& Urdan, 1995, 2001; Wolters, 2004). Specifically, middle school students tend to adopt personal goal orientations that are consistent with the goal structures they perceive in their classroom (Wolters, 2004; Young, 1997) or school (Roeser et al., 1996).

Goal structures also have been linked more directly to indicators of students' engagement, learning, and performance (Ames \& Archer, 1988; Kaplan \& Maehr, 1999; Midgley \& Urdan, 2001; Roeser et al., 1996; Wolters, 2004; Young, 1997). For instance, several studies have linked goal structures to students' use of learning strategies and classroom grades (Midgley \& Urdan, 2001; Murdoch, Hale, \& Weber, 2001; Urdan, Midgley, \& Anderman, 1998; Wolters, 2004). Goal structures have been tied to students' affect and use of coping strategies at school (Kaplan \& Maehr, 1999; Kaplan \& Midgley, 1999). Finally, goal structures have been tied to maladaptive behaviors, including self-handicapping (Midgley \& Urdan, 2001; Urdan, 2004; Urdan et al., 1998), avoidance of help seeking (Karabenick, 2004; Ryan, Gheen, \& Midgley, 1998), 
cheating (Murdoch et al., 2001), and disruptive behavior (Kaplan, Gheen, \& Midgley, 2002). Across these studies, mastery structure tends to be associated with more adaptive cognitive, affective, and achievement outcomes, whereas performance structure is associated with lower levels of adaptive and higher levels of maladaptive outcomes. In sum, understanding goal structures is a growing area of research, and there is a specific need to investigate factors that might affect the type of goal structure emphasized in a classroom or school.

\section{Teachers' Sense of Efficacy}

Early efforts to conceptualize and measure teachers' sense of efficacy (or teachers' self-efficacy) evolved from Rotter's (1966) theory on locus of control and tapped into the extent to which teachers believe that they could control student outcomes regardless of environmental factors (Armor et al., 1976; Ashton \& Webb, 1986; Guskey, 1981; Rose \& Medway, 1981). Subsequent efforts to improve the measurement and understanding of teachers' sense of efficacy have relied more on a social-cognitive framework (Gibson \& Dembo, 1984; Tschannen-Moran, Woolfolk Hoy, \& Hoy, 1998). From this perspective, teachers' sense of efficacy is more analogous to individuals' self-efficacy for learning and can be defined as teachers' judgments or beliefs of their perceived ability to accomplish critical instructional goals even among students who are difficult or unmotivated (Gibson \& Dembo, 1984; Tschannen-Moran \& Woolfolk Hoy, 2001).

Consistent with other social-cognitive forms of self-efficacy, teachers' self-efficacy is thought to derive from their mastery experiences, physiological and emotional feedback, observation of models, and through social persuasion (Bandura, 1997; Tschannen-Moran et al., 1998). As such, teachers' level of selfefficacy is likely to vary depending on the particular instructional situation or group of students they are considering (Raudenbush, Rown, \& Cheong, 1992).

Distinctions among aspects or facets of teacher self-efficacy are also important. Gibson and Dembo (1984) differentiated among generalized and personal self-efficacy for teaching. The former refers to individuals' expectations that teaching can influence student learning, whereas the latter refers to individuals' beliefs that they themselves have the skills necessary to bring about student learning. More recently, Tschannen-Moran and Woolfolk Hoy (2001) distinguished among teachers' sense of efficacy with regard to three critical facets of effective instruction. Teachers' sense of efficacy for instructional strategies refers to a person's confidence that he or she can design and implement activities, tasks, and assessments to facilitate student learning. Teachers' sense of efficacy for classroom management concerns a person's beliefs that he or she can maintain an orderly, organized, nondistractive classroom environment. Finally, teachers' sense of efficacy for student engagement reflects a person's confidence that he or she can help students become and remain involved, invested, or motivated for learning.

\section{Teachers' Sense of Efficacy as an Antecedent to Classroom Goal Structures}

As the most salient decision makers with regard to instructional policies and practices, teachers have an obvious influence on the goal structure within a classroom. Teachers, for instance, make (or can substantially influence) decisions about how to group the students in their class, how to evaluate their work, and the activity structures that are used for instruction. Each of these decisions may determine the type of goal structure within a classroom (Ames, 1992; Kaplan, Middleton, et al., 2002). Moreover, teachers' sense of efficacy may play a role in the outcomes of these types of instructional decisions and, thus, is likely to affect the dominant goal structure in a classroom. Despite this anticipated link, the relation between teachers' sense of efficacy and classroom goal structures has been investigated directly in only one study. Midgley, Anderman, and Hicks (1995) found that a general measure of teachers' self-efficacy was associated positively with their reported use of instructional practices associated with a mastery structure.

Although not focusing on goal structures, other work has examined the role that teachers' sense of efficacy plays in determining teachers' instructional practices and behavior in the classroom. Researchers have found that teachers with a higher sense of efficacy tend to exert more effort in organizing, planning, and delivering their lessons. These teachers also set goals that reveal higher instructional aspirations and enthusiasm than teachers with a lower sense of efficacy (Allinder, 1994). Teachers with high levels of teachers' sense of efficacy also tend to be more open to new ideas and are willing to experiment with innovative instructional methods to better meet the needs of their students (Guskey, 1988; Stein \& Wang, 1988).

When teaching, individuals with a higher sense of efficacy are likely to exhibit different instructional practices, feedback to students, and flexibility. In a study of eight teachers, for instance, Gibson and Dembo (1984) found that those with lower selfefficacy often criticized students who responded with incorrect answers, whereas teachers with higher self-efficacy praised the student for trying and then provided assistance and an additional opportunity to respond. Teachers with higher self-efficacy also tend to exhibit greater warmth toward their students, are responsive to student needs, and are accepting of student initiative (Ashton \& Webb, 1986). Finally, teachers with a greater sense of efficacy also persist longer when confronted with challenges, are more resilient when faced with setbacks, have a greater enthusiasm for teaching, and generally are perceived by others as more effective teachers (Guskey, 1984, 1988; Hall, Burley, Villeme, \& Brockmeier, 1992).

Overall, these studies indicate that teachers' sense of efficacy is related to critical aspects of their instructional attitudes, decision making, and practices in the classroom. It is also likely that, because of these links, teachers' sense of efficacy would be related to the goal structures they foster in their classrooms. However, research directly examining the relation of teachers' self-efficacy and their classroom goal structures is very limited. In the present study, we addressed this gap by investigating the extent to which the three aspects of teachers' sense of efficacy described by Tschannen-Moran and Woolfolk Hoy (2001) can be used to predict the mastery and performance approach structures that teachers report in their classrooms.

\section{Teacher Experience as an Antecedent of Teachers' Sense of Efficacy}

We also investigated two potentially important antecedents of both teachers' self-efficacy and the goal structures they foster: 
teaching experience and academic level. Prior research has shown critical distinctions between novice teachers and their more experienced peers, including differences with regard to their contentspecific and pedagogical knowledge, classroom management skills, problem solving, decision making, and sensitivity to classroom events (Berliner, 1994; Palmer, Stough, Burdenski, \& Gonzales, 2005). More experienced teachers are likely to know more about the content they teach, have different attitudes about their students, and think and behave differently in the classroom when compared with their less experienced peers. Furthermore, many of the characteristics used to differentiate expert from novice teachers have been tied to greater teacher effectiveness (Palmer et al., 2005).

\section{Goal Structures}

A search of the relevant literature produced no studies that specifically examined differences in classroom goal structures on the basis of teachers' level of experience. Still, characteristics similar to those that differentiate more experienced and less experienced teachers have been identified when considering influences on classroom goal structures. Content-specific instructional beliefs and practices, classroom management systems, assessment strategies, and students' involvement in classroom decision making, for example, have been proposed as potential influences on goal structures (Kaplan, Middleton, et al., 2002; Meece, 1991; Turner et al., 2002; Urdan, 1997). Although untested, these parallels suggest that the changes that occur as teachers develop into established professionals may include changes in their classroom goal structures.

\section{Teachers' Sense of Efficacy}

Research evaluating the links between teaching experience and teachers' sense of efficacy has produced mixed results. Consistent with Bandura's (1997) view that enactive experiences, access to competent models, and additional training would improve teachers' self-efficacy, increased experience as a teacher has been associated with higher levels of teacher self-efficacy in some studies (Hoy \& Woolfolk, 1993; Ross, Cousins, \& Gadalla, 1996). For instance, Ross et al. (1996) found evidence in their study of 92 high school teachers that greater teaching experience was associated with higher levels of teachers' sense of efficacy. In contrast, a clear positive association between teaching experience and teachers' sense of efficacy has failed to materialize in other studies (Brousseau, Book, \& Byers, 1988; Ghaith \& Yaghi, 1997; Greenwood, Olejnik, \& Parkay, 1990; Guskey, 1987).

Furthermore, it is difficult to draw firm conclusions from this research because much of it has been conducted with relatively small sample sizes and a relatively restricted range of teaching experience. As well, many of these studies have viewed teachers' sense of efficacy as either a single construct or in terms of general and personal efficacy but did not differentiate among various facets of teachers' personal sense of efficacy. We addressed these issues by investigating differences in each of the three aspects of teachers' sense of efficacy outlined by Tschannen-Moran and Woolfolk Hoy (2001) among a large group of teachers with various amounts of teaching experience.
Academic Level as an Antecedent of Goal Structures and Teachers' Sense of Efficacy

Academic level refers to distinctions in the developmental range or grades within a particular academic context. In public school districts in the United States, these distinctions typically include elementary school, middle or junior high school, and high school. These divisions have not emerged through happenstance but, rather, are the product of a substantial history of debate and interaction among philosophical, cultural, political, and economic forces (Good, 2003; Reese, 2005). Teacher training and certification requirements in many states (including Texas, where the present study was conducted) are differentiated by academic level (Darling-Hammond, 2001). Furthermore, the organizational structure and climate of schools along with the physical, cognitive, and emotional development of students vary across academic levels (Hoy \& Miskel, 2002; Meece, 2002). In short, academic levels represent distinct contexts with unique characteristics derived from their underlying organization and climate, the training and background of the educational personnel, and the students they serve.

\section{Goal Structures}

The predominant goal structures found in classrooms may also vary by academic level. In one direct test, Midgley et al. (1995) found that elementary school teachers reported greater use of instructional practices associated with a mastery structure (but no difference in performance structure) when compared with middle school teachers. Similarly, E. Anderman and Midgley (1997) found that fifth-grade classrooms in an elementary school were perceived by students as stressing mastery-related goals more and performance goals less when compared with sixth-grade middle school classrooms. More indirect evidence for this difference comes from the often-cited drop in adaptive motivational beliefs and attitudes that occur between elementary and middle school (E. Anderman \& Maehr, 1994; E. Anderman \& Midgley, 1997; Wigfield, 1994; Wigfield, Eccles, \& Rodriquez, 1998). Across this same transition, students often view teachers as becoming less caring, more rigid, and less supportive of their emotional needs (L. H. Anderman, 2003; Wentzel \& Wigfield, 1998). One proposed explanation for these effects has been the increasingly performance-focused instructional practices and policies that students encounter as they move into middle or junior high school (E. Anderman \& Midgley, 1997; Wigfield et al., 1998). We extended the work in this area by sampling a greater number of teachers at a wider range of grade levels.

\section{Teachers' Sense of Efficacy}

The characteristics associated with academic levels also may contribute to differences in teachers' sense of efficacy. For instance, the nature and extent of teachers' training, the organization and climate of schools, and developmental changes among students may all affect teachers' self-efficacy. Research supporting this connection, however, is inconclusive. Prior studies have shown some indication that elementary school teachers may hold more positive self-efficacy beliefs than teachers for older students (Guskey, 1987; Ross, 1992). This relation, however, has not been evident in all cases. Raudenbush et al. (1992), for instance, found 
in their study of 315 high school teachers that teachers for seniors tended to express higher levels of self-efficacy than teachers for younger students. Conclusions from these studies also are hampered because of relatively small sample sizes, restricted ranges with regard to academic level, and because studies used undifferentiated forms of teachers' self-efficacy. The present study addressed these outcomes by examining three aspects of teacher self-efficacy among a larger group of elementary, middle, and high school teachers.

\section{Research Questions}

To conclude, the present study has advanced the research investigating both goal structures and teachers' sense of efficacy by addressing three related questions. One, are there differences in the three aspects of teachers' sense of efficacy or the two types of goal structures participants report on the basis of their years of experience as a classroom teacher? Two, are there differences in the three aspects of teachers' sense of efficacy or the two types of goal structures participants report on the basis of whether they teach in an elementary, middle, or high school? Finally, can the three aspects of teachers' sense of efficacy be used to predict the goal structures that teachers report? One notable corollary to this final question is whether different facets of teachers' sense of efficacy are more or less able to predict the mastery or performance structures that teachers report for their classrooms.

\section{Method}

\section{Participants}

Participants for this study were 1,024 (59\%) of the 1,725 prekindergarten through 12th-grade teachers from a large suburban school district in Texas. Although 1,130 teachers elected to participate, 106 teachers were excluded because they worked at the district's alternative school for students with special needs that covered multiple academic levels $(n=30)$ or had missing data on key variables $(n=76)$. The amount of personally identifiable information gathered was limited to ensure confidentiality. Specific information on gender and ethnicity of the participants was not collected. The population of teachers in the district, however, was primarily female $(82 \%)$ and White $(81 \%)$. Participants reported their age using five ranges: $28 \%$ were 29 years old or younger, $26 \%$ were in their $30 \mathrm{~s}, 22 \%$ in their $40 \mathrm{~s}, 22 \%$ in their $50 \mathrm{~s}$, and $2 \%$ were 60 or older. In the final sample, 205 of the participants $(19 \%)$ reported that they had earned some form of postbaccalaureate degree. Participants were responsible for instruction in all subject areas. Elementary school teachers tended to report that they provided instruction for more than a single subject area, whereas teachers at the high school were more likely to be responsible for instruction in just one subject.

\section{Measures}

All data were gathered using a self-report survey conducted via the Internet. The first section of the survey requested demographic information, including items regarding age, highest degree earned, school, subject areas, and years of experience as a teacher. Academic level was created to indicate whether teachers taught in an elementary (PK to Grade $5 ; n=557$ ), middle (Grades $6-8 ; n=$
233 ), or high (Grades $9-12 ; n=234$ ) school. The percentage of participants at each academic level in the sample was very similar to that in the population. Teaching experience reflected whether participants reported that they were in their 1st year of teaching $(n=92)$, had $1-5$ years of experience $(n=361)$, had $6-10$ years of experience $(n=200)$, or had 11 or more years of experience as a teacher $(n=371)$. These intervals were selected to reflect the notion that teachers may change or develop most dramatically within the earlier parts of their career (Richardson \& Placier, 2001).

On the second portion of the survey, teachers completed 24 items from the Teachers' Sense of Efficacy Scale (TschannenMoran \& Woolfolk Hoy, 2001). Participants responded to these items using a 9-point Likert-type scale with anchors at 1 (nothing), 3 (very little), 5 (some degree), 7 (quite a bit), and 9 (a great deal). This instrument was designed by Tschannen-Moran and Woolfolk Hoy (2001) to assess three related aspects of teachers' sense of efficacy. The self-efficacy for instruction items were meant to reflect teachers' confidence in their ability to use a variety of instructional and assessment strategies to meet the needs of all students. The self-efficacy for classroom management items were intended to assess teachers' confidence in their ability to effectively keep order, supervise, or manage their classrooms. The self-efficacy for engagement items were designed to tap into teachers' confidence in their ability to motivate students or to engage them in learning activities. This instrument prompts teachers to reflect on their beliefs overall and not with regard to a particular class of students. Although it does not allow for examination of potentially important intraindividual variation in teachers' sense of efficacy (Raudenbush et al., 1992), assessing teachers' selfefficacy at this level was sufficient for the questions of interest in this study.

Participants also completed nine Likert-styled items from the teacher portion of the Patterns of Adaptive Learning Scales (Midgley et al., 2000). These items used a 9-point response scale with anchors at 1 (strongly disagree), 5 (neither agree nor disagree), and 9 (strongly agree). Four of these items were designed to tap into teachers' self-reported tendency to use instructional practices and policies that would foster a mastery structure in classrooms. Five items were meant to assess teachers' perceived tendency to use instructional strategies thought to create a performance approach structure in classrooms. Although teachers' ability to report accurately on their own instructional behaviors can be questioned, prior research examining goal structures has provided some evidence for the validity of these measures (Kaplan, Gheen, \& Midgley, 2002).

\section{Preliminary Analyses to Evaluate Teacher Self-Efficacy and Goal Structure Items}

Tschannen-Moran and Woolfolk Hoy (2001) concluded that the 24 teachers' sense of efficacy items form three 8-item scales. Prior work also provided a theoretical rationale for using the 9 goal structure items to form two scales (Midgley et al., 1998). Nevertheless, an analysis of the factor structure of these items seemed warranted for three reasons. One, data were collected using a new methodology. Two, the sample included a larger number and variety of teachers with regard to experience and academic level than had been examined previously. Three, most of the work exploring goal structures has relied on student and not teacher reports. 
A three-step process to examine the factor structure of the teacher's self-efficacy and goal structure items was conducted. First, the total sample was randomly split into an initial and a validation sample. Second, using the initial sample, we conducted an exploratory factor analysis separately for the teachers' sense of efficacy and goal structure items. Finally, confirmatory factor analyses were conducted using the validation sample. Although there was less than $2 \%$ of missing data for any individual item, we used mean imputation to reduce the effect of missing data for these preliminary analyses.

Factor analysis of teachers' sense of efficacy items. An exploratory factor analysis using principal axis factoring and a varimax rotation conducted on the 24 self-efficacy items produced eigenvalues and a scree plot that indicated a two-, three-, or four-factor solution was plausible. To be consistent with Tschannen-Moran and Woolfolk Hoy (2001), we pursued the three-factor solution, which accounted for $66 \%$ of the total variance. As presented in Table 1, individual factor loadings generally were strong and consistent with earlier findings in that they supported factors representing self-efficacy for instruction, selfefficacy for management, and self-efficacy for engagement. Six items, however, did not load as expected, had weak primary loadings $(<.50)$, or had elevated crossover loadings $(>.40)$.

Using the validation sample, we conducted a confirmatory factor analysis using maximum likelihood estimates. An initial model that reflected the original three 8-item correlated factors identified by Tschannen-Moran and Woolfolk Hoy (2001) was tested but showed poor fit to the data: $\chi^{2}(249, N=512)=1,400.62$ comparative fit index $(\mathrm{CFI})=.86$, normed fit index $(\mathrm{NFI})=.84$, Tucker-Lewis index $(\mathrm{TLI})=.85$, root-mean-square error of approximation $($ RMSEA) $=.10$. Following guidelines for a specification search noted by Schumacker and Lomax (2004), as well as results from the exploratory factor analyses, we developed an alternative model in which 6 items were eliminated and four pairs of error terms were allowed to correlate. This model showed a more reasonable degree of fit to the data: $\chi^{2}(128, N=512)=$ $577.65, \mathrm{CFI}=.93, \mathrm{NFI}=.91, \mathrm{TLI}=.91, \mathrm{RMSEA}=.08$, and was used as the basis for creating the three self-efficacy scales used in the remainder of the study. These scales represented teachers' beliefs about their self-efficacy for instruction ( 8 items; $\alpha=.93$ ), self-efficacy for management ( 6 items; $\alpha=.92$ ), and self-efficacy for engagement ( 4 items; $\alpha=.85$ ). The former two scales reflected very similar underlying constructs as those described by Tschannen-Moran and Woolfolk Hoy. The modified self-efficacy for engagement scale, in contrast, appeared to reflect a greater focus on teachers' confidence in their ability to foster students' achievement motivation.

Factor analysis of goal structure items. Exploratory factor analyses of the nine goal structure items indicated that a two-factor solution was optimal and accounted for $49 \%$ of the total variance. The five performance structure items loaded onto the first factor, and the four items designed to assess mastery structure were associated with the second (see Table 2). All of the items loaded as projected, although three items had weak individual loadings.

Table 1

Rotated Factor Scores for Teachers' Sense of Efficacy Items

\begin{tabular}{|c|c|c|c|}
\hline Item and key text ${ }^{\mathrm{a}}$ & $\begin{array}{c}\text { Factor 1: } \\
\text { Self-Efficacy } \\
\text { for Instruction }\end{array}$ & $\begin{array}{c}\text { Factor 2: } \\
\text { Self-Efficacy } \\
\text { for Management }\end{array}$ & $\begin{array}{c}\text { Factor 3: } \\
\text { Self-Efficacy } \\
\text { for Engagement }\end{array}$ \\
\hline 11. Craft good questions for students & .74 & & \\
\hline 24. Provide challenges for capable students & .73 & & \\
\hline 20. Alternative explanations for confused students & .71 & .35 & \\
\hline 18. Use a variety of assessment strategies & .71 & & \\
\hline 10. Gauge student comprehension & .69 & & \\
\hline 23. Implement alternative strategies & .65 & .35 & \\
\hline 17. Adjust lessons to the proper level & .65 & & \\
\hline 7. Respond to difficult questions & .62 & & \\
\hline 19. Keep problem students from ruining lesson & & .75 & \\
\hline 13. Get children to follow classroom rules & & .75 & \\
\hline 15. Calm a student who is noisy & & .74 & \\
\hline 3. Control disruptive behavior & & .71 & \\
\hline 16. Establish a management system & .51 & .68 & \\
\hline 21. Respond to defiant students & .37 & .66 & \\
\hline 8. Establish routines ${ }^{\mathrm{b}}$ & .56 & .45 & \\
\hline 5. Make behavior expectations clear $^{\mathrm{b}}$ & .41 & .45 & \\
\hline 4. Motivate students who show low interest & & .37 & .75 \\
\hline 1. Get through to the most difficult students & & .35 & .62 \\
\hline 6. Get students to believe they can do well & .38 & & 61 \\
\hline 9. Help students value learning & .39 & .36 & .59 \\
\hline 14. Improve understanding of failing student ${ }^{\mathrm{b}}$ & .51 & & .53 \\
\hline 2. Help students think criticallyb & .44 & & .49 \\
\hline 12. Foster student creativity ${ }^{b}$ & .62 & & .42 \\
\hline 22. Assist families in helping children ${ }^{\mathrm{b}}$ & .47 & & .35 \\
\hline
\end{tabular}

Note. $n=512$. Factor scores below .35 are not listed.

${ }^{a}$ Each item has been paraphrased. Item numbers reflect those used in Tschannen-Moran and Woolfolk Hoy (2001), where full text of items can be found. ${ }^{b}$ Items not used to construct scales for use in subsequent analyses. 
Table 2

Rotated Factor Scores for Goal Structure Items

\begin{tabular}{lcc}
\hline \multicolumn{1}{c}{ Item and key text $^{\mathrm{a}}$} & $\begin{array}{c}\text { Factor 1: } \\
\text { Performance } \\
\text { Structure }\end{array}$ & $\begin{array}{c}\text { Factor 2: } \\
\text { Mastery } \\
\text { Structure }\end{array}$ \\
\hline 17. Help students compare performance to others & .70 & .65 \\
19. Encourage students to compete & .62 & .60 \\
21. Point out students who do well & .40 & .79 \\
9. Display work of highest achieving students & & .65 \\
1. Give special privileges to students who do best ${ }^{\mathrm{b}}$ & .41 \\
26. Give range of assignments matched to skill level & .35 \\
11. Provide different activities so students can choose & \\
13. Consider improvement when giving grades & \\
4. Make special effort to recognize progress ${ }^{\mathrm{b}}$ & & \\
\hline & & \\
Note. $n=512$. Factor scores below .35 are not listed. & \\
${ }^{\mathrm{a}}$ Each item has been paraphrased. Item numbers reflect those used in Midgley et al. (2000), where full text of \\
items can be found. ${ }^{\mathrm{b}}$ Item not used to construct scales for use in later analyses.
\end{tabular}

A maximum likelihood confirmatory factor analysis was conducted for the nine goal structure items using the validation sample. An initial model in which the four mastery structure items and the five performance structure items formed separate but correlated factors provided an adequate fit to the data, $\chi^{2}(26, N=$ $512)=85.50, \mathrm{CFI}=.94, \mathrm{NFI}=.92, \mathrm{TLI}=.92, \mathrm{RMSEA}=.07$. A specification search and the results of the exploratory analyses, however, suggested that it could be improved with the elimination of two items. The model resulting from these deletions showed an improved fit to the data, $\chi^{2}(13, N=512)=35.12$, CFI $=.98$, $\mathrm{NFI}=.96, \mathrm{TLI}=.96, \mathrm{RMSEA}=.06$, and was used to form scales for mastery structure ( 3 items; $\alpha=.66$ ) and performance approach structure (4 items; $\alpha=.76$ ).

\section{Procedure}

In November, teachers in the district were sent an e-mail from a district administrator that briefly described the survey, its purpose in general terms, and requested that the teacher complete it. The survey was framed and completed as part of a larger school district effort to evaluate and improve teacher training. Teachers who chose to participate clicked on a hyperlink in the e-mail that took them to the online survey. When completed, data were transmitted directly to a database on a secure server.

\section{Results}

Results are divided into two sections. First, we address the first two research questions by exploring the relations of teaching experience and academic level with teachers' self-efficacies and classroom goal structures. Second, we discuss the extent to which teacher experience and academic level, along with the three selfefficacy variables, can be used to predict the two goal structures.

\section{Linking Academic Level and Experience to Teachers' Sense of Efficacy and Goal Structure}

Descriptive information for the teachers' sense of efficacy and goal structure variables is presented in Table 3. This information is provided for each of the three academic level groups and the four teacher experience groups, as well as for the sample as a whole. To investigate differences in these scores, we conducted 3 (academic level) $\times 4$ (teaching experience) multivariate analyses of variance (MANOVAs) separately for the self-efficacy and goal structure variables.

Teachers' sense of efficacy. The multivariate test for the analyses examining the three self-efficacy scales together indicated main effects for academic level, $\lambda=.94, F(6,2020)=11.23, p<$ .001 , and teaching experience, $\lambda=.93, F(9,2458)=8.27, p<$ .001 , but no interaction, $\lambda=.97, F(18,2857)=1.58, p>.05$. Follow-up tests were conducted separately for each facet of teacher self-efficacy.

The between-subjects follow-up tests for self-efficacy for instruction indicated no effect of academic level and a significant but modest effect for teacher experience, $F(3,1012)=13.04, p<$ $.001, \eta^{2}=.04$. To investigate this effect, we investigated differences among the experience groups using Tukey's honestly significant difference (HSD) post hoc comparisons (see Table 3 for means and standard deviations). These comparisons indicated that 1st-year teachers, on average, reported lower levels of efficacy for instruction than participants in the groups of teachers with 1-5 years of experience $(\delta=.30, p<.05), 6-10$ years of experience $(\delta=.54, p<.05)$, and 11 or more years of experience $(\delta=.68$, $p<.05)$. As well, teachers with $1-5$ years of experience reported lower levels of self-efficacy for instruction than those with 6-10 years of experience $(\delta=.25, p<.05)$ and those with 11 or more years of experience $(\delta=.39, p<.05)$. There was no difference in self-efficacy for instruction among teachers within the two highest levels of experience.

The follow-up analyses revealed similar findings with regard to self-efficacy for management (see Table 3). The between-subjects follow-up tests indicated no effect of academic level and an effect for teacher experience, $F(3,1012)=7.11, p<.001, \eta^{2}=.02$. Post hoc comparisons indicated that the 1 st-year teachers reported lower self-efficacy for management than teachers with more than 10 years of experience $(\delta=.50, p<.05)$. Teachers with $1-5$ years of experience also tended to report lower levels of self-efficacy for management than the most experienced teachers $(\delta=.25, p<$ $.05)$.

The between-subjects tests for self-efficacy for engagement revealed a different pattern. For this aspect of teacher self-efficacy, 
there was a modest effect of academic level, $F(2,1012)=23.72$, $p<.001, \eta^{2}=.04$, but no effect of experience. Post hoc comparisons indicated that elementary teachers tended to report higher levels of self-efficacy for engagement than teachers at a middle $(\delta=.32, p<.05)$ or high $(\delta=.53, p<.05)$ school, whereas these latter two groups were similar.

Goal structures. The MANOVA examining goal structures indicated main effects for academic level, $\lambda=.95, F(4,2018)=$ 14.27, $p<.001$, but no effect of teaching experience and no interaction. The follow-up tests revealed main effects for academic level for both mastery structure, $F(2,1010)=8.90, p<.001$, $\eta^{2}=.02$, and for performance structure, $F(2,1010)=13.37, p<$ $.001, \eta^{2}=.03$. In addition, Tukey's HSD post hoc tests indicated that, on average, teachers at the elementary level reported higher levels of mastery structure and lower levels of performance structure than teachers at a middle $(\delta \mathrm{s}=.20$ and .27 , respectively, $p s<$ $.05)$ or high school $(\delta=.42$ and .28 , respectively, $p \mathrm{~s}<.05)$. Middle and high school teachers reported similar goal structures (see Table 3).

\section{Predicting Teacher Reported Mastery and Performance Goal Structures}

The bivariate correlations among the teachers' sense of efficacy and goal structure variables were consistent with expectations (see Table 4). As indicated by the strong correlations among the three self-efficacy variables $(r s>.68)$, participants who reported feeling confident about one aspect of teaching tended to feel confident about other aspects as well. Mastery structure was moderately correlated $(.23<r$ s $<.39)$ with each aspect of teacher selfefficacy, whereas performance structure was not $(r \mathrm{~s}<.10)$. The goal structures were positively correlated with one another $(r=$ $.25)$.

Two-step hierarchical regressions were conducted to explore further the relations among the three aspects of teachers' selfefficacy and the two goal structures. In the first step, we entered two dichotomous variables representing academic level and three dichotomous variables representing experience as predictors. Results from this step evaluate relations similar to those in the MANOVAs described above and generally were consistent with these prior analyses. Hence, findings from Step 1 of the regressions are not discussed but are presented in Table 5 .

In the second step, we added the three sense of efficacy variables together as predictors. This two-step process was chosen to conform to a general model in which background characteristics

Table 4

Correlations Among Teachers' Sense of Efficacy and Goal Structure Scales

\begin{tabular}{lccccc}
\hline \multicolumn{1}{c}{ Variable } & 1 & 2 & 3 & 4 & 5 \\
\hline 1. Self-efficacy for instruction & - & $.69^{* *}$ & $.68^{* *}$ & $.38^{* *}$ & $.09^{*}$ \\
2. Self-efficacy for management & & - & $.68^{* *}$ & $.24^{* *}$ & .04 \\
3. Self-efficacy for engagement & & - & $.35^{* *}$ & .05 \\
4. Mastery structure & & & & - & $.25^{* *}$ \\
5. Performance structure & & & & & - \\
\hline
\end{tabular}

Note. $\quad N=1,024$.

${ }^{*} p<.05 . \quad{ }^{* * *} p<.01$. 
Table 5

Summary of Hierarchical Regression Analyses Predicting Mastery and Performance Structures

\begin{tabular}{|c|c|c|c|c|c|c|}
\hline \multirow[b]{2}{*}{ Variable } & \multicolumn{3}{|c|}{ Mastery structure } & \multicolumn{3}{|c|}{ Performance structure } \\
\hline & $B$ & $S E B$ & $\beta$ & $B$ & $S E B$ & $\beta$ \\
\hline \multicolumn{7}{|l|}{ Step 1} \\
\hline Middle school & -0.32 & 0.13 & $-.08^{*}$ & 0.76 & 0.14 & $.18^{* *}$ \\
\hline High school & -0.46 & 0.13 & $-.12^{* *}$ & 0.51 & 0.14 & $.12^{\text {** }}$ \\
\hline 1 st-year teacher & -0.39 & 0.19 & $-.07^{*}$ & -0.48 & 0.20 & $-.08^{*}$ \\
\hline Teaching $1-5$ years & -0.23 & 0.12 & -.07 & -0.01 & 0.13 & .00 \\
\hline Teaching 5-10 years & -0.04 & 0.14 & -.01 & -0.10 & 0.15 & -.02 \\
\hline \multicolumn{7}{|l|}{ Step 2} \\
\hline Middle school & -0.18 & 0.12 & -.05 & 0.80 & 0.14 & $.19^{\text {** }}$ \\
\hline High school & -0.26 & 0.12 & $-.07^{*}$ & 0.57 & 0.14 & $.13^{* * *}$ \\
\hline 1st-year teacher & -0.05 & 0.18 & -.01 & -0.40 & 0.21 & -.06 \\
\hline Teaching $1-5$ years & -0.06 & 0.11 & -.02 & 0.02 & 0.13 & .01 \\
\hline Teaching $5-10$ years & -0.01 & 0.13 & .00 & -0.10 & 0.15 & -.02 \\
\hline Self-efficacy for instruction & 0.49 & 0.07 & $.31^{* * *}$ & 0.15 & 0.08 & .09 \\
\hline Self-efficacy for management & -0.16 & 0.06 & $-.12^{* *}$ & -0.10 & 0.07 & -.07 \\
\hline Self-efficacy for engagement & 0.27 & 0.06 & $.21^{* * *}$ & 0.09 & 0.07 & .07 \\
\hline
\end{tabular}

Note. $\quad N=1,024$. Mastery structure: $R^{2}=.02, p<.001$, for Step $1 ; \Delta R^{2}=.15, p<.001$, for Step 2 . Performance structure: $R^{2}=.04, p<.001$, for Step $1 ; \Delta R^{2}=.01, p<.05$, for Step 2 .

${ }^{*} p<.05 .{ }^{* *} p<.01$.

are viewed as affecting teachers' self-efficacy and all these factors together influence the goal structures in a classroom. This process also allowed for an evaluation of the extent to which the teacher self-efficacy variables as a group explained variance in the two goal structures. Results from these analyses are presented in Table 5 and discussed below.

Mastery structure. Adding the three sense of efficacy variables in the second step explained an additional $15 \%$ of the variance in mastery structure, $\Delta R^{2}=.15, \Delta F(3,1013)=61.24$, $p<.001$. Self-efficacy for instruction $(\beta=.31, p<.001)$ and self-efficacy for engagement $(\beta=.21, p<.001)$ were positive predictors of mastery structure (see Table 5) in this step. On average, teachers who felt more confident in their ability to help students learn and to be engaged in learning tasks reported using instructional practices thought to foster a mastery goal orientation in students. Unexpectedly, self-efficacy for management was associated with lower levels of mastery structure $(\beta=-.12, p<.01)$ after accounting for the other predictors. Further examination of this result, however, indicated that it was likely due to a suppressor effect resulting from the elevated correlations among the teachers' sense of efficacy variables. The presence of this effect was supported by the positive bivariate correlation between self-efficacy for management and mastery structure, as well as additional analyses that showed self-efficacy for management was a positive predictor of mastery structure when the other two teacher selfefficacies were excluded as predictors.

Performance structure. Adding the sense of efficacy variables in Step 2 increased the amount of variance explained in performance structure, $\Delta R^{2}=.01, \Delta F(3,1013)=3.39, p<.05$, by a significant but small amount (see Table 5). None of the teacher self-efficacy variables individually accounted for a significant portion of the variance in performance structure. Even when accounting for teachers' sense of efficacy, elementary teachers tended to report less frequent use of instructional practices associated with a performance approach goal orientation in students than teachers in a middle $(\beta=.19, p<.001)$ or high $(\beta=.13, p<$ .001) school.

\section{Discussion}

Overall, this study provides insight into how teachers' selfreported motivational beliefs and instructional practices may be linked, and how these constructs may vary on the basis of teachers' experience and the academic level at which they teach. In this section, we discuss findings with regard to each of the three questions proposed earlier: (a) Do participants' reported sense of teacher efficacy or goal structures vary based on the amount of experience they have as a classroom teacher? (b) Do teachers' sense of efficacy or goal structures vary by the academic level in which they teach? (c) Can the three aspects of teachers' sense of efficacy be used to understand or predict the goal structures teachers report? Theoretical and practical implications of our findings are discussed, as well as the limitations of the study.

\section{Teaching Experience}

Findings are consistent with some prior research conducted with smaller sample sizes and with undifferentiated measures showing experience-related improvements in teachers' sense of efficacy (Ross et al., 1996). The distinctions among facets of teachers' sense of efficacy proved noteworthy, however, in that only two of them varied by teacher experience. Although the effects were modest, findings did indicate that teachers with additional years of experience felt more confident in their ability to employ instructional and assessment practices that would benefit even their most difficult-to-reach students. As well, the more experienced teachers had greater confidence in their ability to keep order or avoid disruptions that might make instruction and learning difficult in their classrooms. These findings are consistent with research on teacher education showing that new teachers continue to develop 
the instructional and management knowledge and skills necessary to be expert teachers (Richardson \& Placier, 2001; Stein \& Wang, 1988). Given that teachers' sense of efficacy generally has been associated with more positive teacher behaviors, attitudes, and interactions with students (Ashton \& Webb, 1986; Guskey, 1984, 1988; Hall et al., 1992), these findings also provide further evidence as to why more experienced teachers may be more effective instructors than their less experienced peers.

The underlying reasons for the greater confidence in some areas expressed by the more experienced teachers is uncertain. One reason that self-efficacy is likely to be higher among more experienced teachers is attrition. Those who decide to leave a profession, generally, are less skilled and less confident in their abilities than those who continue in it (Bandura, 1997). This attrition pattern means that groups of more experienced teachers would tend to report higher average levels of confidence in their abilities when compared with groups of less experienced teachers, even if individuals' teacher self-efficacy is not increasing. This explanation may be especially important to consider with teaching because it has a high rate of attrition for those newly entering the profession (Ingersoll, 2001).

A second explanation is that more experienced teachers have obtained additional and more specific training needed to be effective in these areas of their professional responsibilities. This possibility is supported by prior research showing that teacher training may be associated with increases in teachers' sense of efficacy (Fritz, Miller-Heyl, Kreutzer, \& MacPhee, 2001; Yost, 2002). A third but related explanation is that teachers with a longer tenure in the profession have had more opportunities to develop the skills needed to be a successful teacher through additional direct experience. That is, they have been exposed to and have overcome challenging situations that allowed them to build their skills and concomitantly their confidence. Both of these latter explanations are consistent with the argument that efficacy for particular tasks increases through enactive mastery experiences (Bandura, 1997; Labone, 2004).

More consistent with a second influence on efficacy identified by Bandura (1997), teachers with more experience also have had a greater opportunity to be exposed to competent models. In other words, more experienced teachers may demonstrate increased selfefficacy in some areas because they have watched and learned from their colleagues the instructional and management skills needed to be more confident. Note, however, that we did not evaluate actual skills, only teachers' confidence in their own abilities.

The current data do not allow for a specific evaluation of the relative viability of these explanations. More than likely, the self-efficacy differences found among the teacher experience groups emanate from some combination of attrition, enactive experiences, training, and other on-the-job experiences. Additional research designed to test which of various explanations is most critical would be useful, however. For instance, research that follows teachers over a period of time to evaluate individual changes in self-efficacy with experience, or that assesses the amount of in-service training teachers obtain would be informative. Further research also is needed to explore why there were experience-related differences in teachers' sense of efficacy for management and instruction but not efficacy for engagement.
Finally, the groups in the present study did not distinguish among those with more than 10 years of experience. This lack of differentiation among the most-experienced teachers may mask changes in teachers' self-efficacy that may occur toward the end of their careers.

Participants' experience was much less of a factor in explaining variations in their reported goal structures. Results showed no differences in either goal structure on the basis of teachers' years of experience. This finding is distressing, in part, because of the continuing perception regarding the relative merits of performance-based and mastery-based classroom goal structures and students' personal goal orientations (E. Anderman \& Wolters, 2006; Urdan, 1997). Unfortunately, it appears as if experiencerelated changes in teachers' skills as instructors do not include the more frequent use of instructional practices likely to foster the adoption of mastery goals by students or the less frequent use of practices and policies associated with the adoption of performance goals. That is, development and maturity as a teacher do not appear to include a movement toward instructional practices, policies, or procedures associated with fostering what many consider a more adaptive motivational climate in the classroom.

\section{Academic Level}

Findings support the increasing recognition that critical characteristics of the classroom motivational climate vary across academic levels. Most notably, findings provided relatively robust evidence confirming the expectation that classroom instructional practices, policies, and procedures reported most often within elementary schools provide a motivational atmosphere based more on mastery goals and less on performance approach goals when compared with those in middle and high schools. These findings are consistent with earlier results examining teacher and student reports of goal structures (E. Anderman \& Midgley, 1997; Midgley et al., 1995), and with the drop in students' mastery orientation and increases in their performance orientation found across the transition to middle school (E. Anderman \& Maehr, 1994; E. Anderman \& Midgley, 1997). Using a wider range and larger number of teachers, the present study has provided additional evidence that instructional processes within elementary school contexts stress individual learning and overcoming challenges, whereas demonstrating one's ability and outperforming others are promoted more within middle and high school settings.

Along with this shift in motivational climate are changes in teachers' sense of efficacy for sustaining motivation. Although the effects were not large, teachers for the higher grades tended to report less confidence in their ability to engage students meaningfully in the learning process. Together, these findings indicate that middle and high school teachers' level of confidence in their ability to keep students engaged is eroding at the same time that they are reporting more frequent use of instructional practices associated with performance approach goals and less with mastery goals. This pattern is intriguing and suggests a need for further study of the relations between teachers' beliefs about their ability to successfully accomplish instructional tasks and the instructional practices they reportedly use in the classroom. 


\section{Relation of Teachers' Sense of Efficacy to Classroom Goal Structures}

One central goal of the present study was to investigate the relations between facets of teachers' sense of efficacy and the motivational climate teachers foster. Although data were correlational, analyses were consistent with the notion that teachers' sense of efficacy might influence the type of instructional practices and policies they use. In fact, teachers' beliefs about their ability to successfully accomplish different aspects of being a teacher could be used to explain both the mastery and performance approach structures they reported. This link is important because it provides a connection between different classroom motivational processes. In particular, it provides evidence that individuals' beliefs about their teaching abilities are linked to instructional practices, policies, or procedures previously found to influence students' motivation for learning and achievement.

Interestingly, the three aspects of teachers' sense of efficacy explained a much larger portion of the variance for mastery structure $(15 \%)$ than for performance structure $(1 \%)$ after accounting for teachers' experience and academic level. One empirical reason for this contrast appeared to be that teachers' self-efficacy for instruction was strongly related only to mastery structure. Hence, teachers who reported greater confidence in their ability to modify their instruction and assessment strategies to fit student needs also tended to report using instructional practices that focus students on improvement, overcoming a challenge, and learning as much as possible. In contrast, teachers' sense of efficacy for instruction seemed to have no bearing on their reported performance approach goal structure.

Teachers' sense of efficacy for management and engagement showed more consistency in their relations to their reported goal structures. Teachers who were more confident in their ability to get students engaged in learning reported greater use of instructional practices consistent with a mastery structure as well as those associated with a performance approach structure. This pattern suggests that teachers may see both types of goal structures as viable pathways for getting students engaged in the classroom. At the same time, teachers' confidence in their abilities to keep order in the classroom was not strongly associated with their use of instructional practices linked to either mastery and performance approach goal structures. These teachers may rely more on classroom practices that maintain order but do not necessarily facilitate either mastery- or performance approach-based reasons for students to be motivated. One theoretical implication of the consistency of these relations is that the two goal structures are not opposite ends of a continuum but perhaps are more orthogonally related. The modest positive bivariate correlation between the two goal structures also supports this view.

\section{Conceptual Understanding of Teachers' Sense of Efficacy and Goal Structures}

Although not a focus of this research, findings are also valuable for the insight they provide into the measurement of teachers' sense of efficacy and goal structure. Using the same items, Tschannen-Moran and Woolfolk Hoy (2001) found that teachers' self-efficacy was best conceptualized as three related dimensions reflecting teachers' sense of efficacy for instruction, management, and engagement. On the basis of both exploratory and confirmatory factor analyses with a large number of teachers with varying degrees of experience across all academic levels, our results tend to confirm these earlier distinctions with some minor conceptual adjustment to the efficacy for engagement dimension. Findings indicated that efficacy for engagement might best be conceptualized as teachers' beliefs about their ability to motivate and keep students meaningfully engaged in their academic work. Discarded from this revised version of self-efficacy for engagement is the focus on teachers' confidence in their ability to get students to think critically or be cognitively engaged at a deeper level. The disparate relations of these facets of teachers' self-efficacy to the two goal structures provide evidence to support their ongoing conceptual differentiation. Although our findings back at least three distinct aspects of teachers' self-efficacy, they do not preclude additional aspects. For instance, the ability to engage students in critical thinking or influence students' social skills might be viable candidates (Labone, 2004).

\section{Practical and Educational Implications}

One implication is derived not from the study's findings per se but from the methodology employed. Participants were recruited via an e-mail notice, and data were gathered using an Internet survey. Although likely bolstered by the district's endorsement of the study, the participation rate, amount of missing data, and scale reliabilities all indicated that this method of recruitment and data collection can be at least as effective as would be expected using traditional instruments in a similar situation. In fact, because raw data were automatically transferred into an electronic database, this method was simpler, quicker, and less prone to input errors than paper-and-pencil survey methods. These results support the growing opinion that Web-based surveys provide an effective and efficient alternative for the collection of psychological data (Gosling, Vazire, Srivastava, \& John, 2004).

Another important implication follows from the higher levels of efficacy found among the more experienced teachers. As noted above, some of the reasons that these teachers express greater levels of efficacy may relate to on-the-job experiences and training that are viable candidates for intervention (Bandura, 1997; Labone, 2004). For instance, improving teachers' skills through direct training opportunities should serve to increase their self-efficacy in all areas of teaching. As well, efforts to provide new teachers with more frequent opportunities to observe or interact with expert teachers or other more skilled models should increase their selfefficacy. In sum, there may be a variety of ways through which beginning teachers can be supported, trained, or supervised that would allow them to develop increased self-efficacy more quickly. Paired with earlier work showing the adaptive outcomes associated with greater teacher self-efficacy (Ashton \& Webb, 1986; Guskey, 1984, 1988; Hall et al., 1992), our findings suggest that these efforts would be a worthwhile endeavor.

From a more instructional viewpoint, another implication is that the mastery goal structure within a classroom might be affected through interventions that target the beliefs teachers hold regarding their instructional abilities. Although still emerging, there is some evidence supporting the adaptiveness of a mastery structure (Ames, 1992; E. Anderman \& Maehr, 1994; Wolters, 2004). We found that teachers' sense of efficacy for instructional strategies 
and for engagement had positive relations with mastery structure. Training designed to increase teachers' confidence in their ability to use varied and effective features of instruction and assessment, therefore, may eventuate in a greater mastery structure within the classroom. As well, efforts to increase teachers' confidence for getting students motivated and meaningfully engaged in academic tasks also may eventuate in a greater mastery structure in the classroom.

\section{Limitations}

One limitation worth noting is the inability to draw causal conclusions from the correlational data in this study. The model used to guide analyses is consistent with the view that teachers' self-efficacy affects the instructional decisions that ultimately determine the goal structures in their classrooms. It is also possible, however, that teachers' use of the instructional strategies that form a mastery or performance approach structure affects their selfefficacy for teaching. For instance, grading procedures that reward effort or progress (i.e., increase mastery structure) may foster increased student involvement and allow teachers to feel more efficacious about engagement. Another possibility is that the relations discovered here emanate from a common relation with contextual or structural features of the school not examined in this study. For instance, characteristics of the students in their classroom could influence both teachers' self-efficacy beliefs and the goal structures they promote. As well, district-level policies might affect teachers' practices as well as their confidence regarding the accomplishment of key instructional responsibilities. Additional research is needed to better understand the most likely causal ordering among these constructs.

A second limitation also was based on how constructs in this study were measured. We assessed teachers' self-efficacy and goal structures at a general level and not in relation to a particular context, task, or group of students. These motivational beliefs and instructional practices, however, may vary within individual teachers when asked about different classes they face within a day (Raudenbush et al., 1992). Research that explores these relations in more context-specific ways would be informative and provide insight on this issue.

A third limitation of our findings is the confounding of academic level and the number of students or subject areas taught. As is typical, the elementary school teachers in the present study were responsible for fewer different groups of students than the middle and high school teachers. At the same time, individual elementary teachers were responsible for more subject areas (e.g., reading, math, science) than the middle and high school teachers. This entangling of the number of students and subject areas taught with more age-based distinctions make it impossible to draw strong conclusions regarding the underlying basis for the differences found with regard to academic level. These differences may derive from many factors, including developmental changes among the students, the number and diversity of students taught, or the extent and complexity of the content knowledge teachers were responsible for covering. A study that makes similar comparisons in groups of elementary and middle or high school teachers that are more consistent with regard to the number of students or subject areas taught would help to address this question.

\section{Conclusions}

To summarize, the present study adds to the research on motivation by beginning to connect two separate frameworks developed to better understand classroom influences on students' motivation and subsequent learning and achievement. In particular, we examined how motivational beliefs held by teachers were associated with instructional practices thought to affect students' motivation. In support of an association between these frameworks, findings revealed important links between different aspects of teachers' perceived sense of efficacy and their reported tendency to create mastery and performance structures in their classrooms. Moreover, the present research adds to earlier work indicating that the motivational constructs associated with these frameworks are a function of both individual differences in teachers (i.e., experience teaching), as well as variations in the contexts within which teachers work (i.e., academic level).

\section{References}

Allinder, R. M. (1994). The relationship between efficacy and the instructional practices of special education teachers and consultants. Teacher Education and Special Education, 17, 86-95.

Ames, C. (1992). Classrooms: Goals, structures, and student motivation. Journal of Educational Psychology, 84, 261-271.

Ames, C., \& Archer, J. (1988). Achievement goals in the classroom: Student's learning strategies and motivational processes. Journal of Educational Psychology, 80, 260-267.

Anderman, E., \& Maehr, M. (1994). Motivation and schooling in the middle grades. Review of Educational Research, 64, 287-309.

Anderman, E., \& Midgley, C. (1997). Changes in achievement goal orientations, perceived academic competence, and grades across the transition to middle-level school. Contemporary Educational Psychology, 22, 269-298.

Anderman, E., \& Wolters, C. (2006). Values, goals and affect: Influences on student motivation. In P. Alexander \& P. Winne (Eds.), Handbook of educational psychology (2nd ed., pp. 369-389). Mahwah, NJ: Erlbaum.

Anderman, E., \& Young, A. (1994). Motivation and strategy use in science: Individual differences and classroom effects. Journal of Research in Science Teaching, 31, 811-831.

Anderman, L. H. (2003). Academic and social perceptions as predictors of change in middle school students' sense of belonging. The Journal of Experimental Education, 72, 5-22.

Armor, D., Conroy-Oseguera, P., Cox, M., King, N., McDonnell. L., Pascal, A., et al. (1976). Analysis of the school preferred reading programs in selected Los Angeles minority schools (Report No. R-2007LAUSD). Santa Monica, CA: Rand Corporation.

Ashton, P. T., \& Webb, R. B. (1986). Making a difference: Teachers' sense of efficacy and student achievement. New York: Longman.

Bandura, A. (1997). Self-efficacy: The exercise of control. New York: Freeman.

Berliner, D. (1994). Expertise: The wonder of exemplary performances. In J. Mangieri \& C. Block (Eds.), Creating powerful thinking in teachers and students: Diverse perspectives (pp. 161-186). New York: Harcourt Brace.

Brousseau, B., Book, C., \& Byers, J. (1988). Teacher beliefs and the cultures of teaching. Journal of Teacher Education, 39(6), 33-39.

Church, M., Elliot, A., \& Gable, S. (2001). Perceptions of classroom environment, achievement goals, and achievement outcomes. Journal of Educational Psychology, 93, 43-54.

Darling-Hammond, L. (2001). Standard setting in teaching: Changes in licensing, certification, and assessment. In V. Richardson (Ed.), Handbook of research on teaching (4th ed., pp. 751-776). Washington, DC: American Educational Research Association. 
Fritz, J. J., Miller-Heyl, J., Kreutzer, J. C., \& MacPhee, D. (2001). Fostering personal teacher efficacy through staff development and classroom activities. Journal of Educational Research, 88, 200-208.

Ghaith, G., \& Yaghi, H. (1997). Relationships among experience, teacher efficacy, and attitudes toward the implication of instructional innovation. Teaching and Teacher Education, 13, 451-458.

Gibson, S., \& Dembo, M. (1984). Teacher efficacy: A construct validation. Journal of Educational Psychology, 76, 569-582.

Good, T. (Ed.). (2003). American education: Yesterday, today, and tomorrow. Chicago: University of Chicago Press.

Gosling, S., Vazire, S., Srivastava, S., \& John, O. (2004). Should we trust Web-based surveys? A comparative analysis of six preconceptions about Internet questionnaires. American Psychologist, 59, 93-104.

Graham, S., \& Weiner, B. (1996). Theories and principles of motivation. In D. Berliner \& R. Calfee (Eds.), Handbook of educational psychology (pp. 63-84). New York: Simon \& Schuster Macmillan.

Greenwood, G., Olejnik, S., \& Parkay, F. (1990). Relationships between four teacher efficacy belief patterns and selected teacher characteristics. Journal of Research and Development in Education, 23, 102-107.

Guskey, T. R. (1981). Measurement of responsibility teachers assume for academic success and failures in the classroom. Journal of Teacher Education, 32, 44-51.

Guskey, T. R. (1984). The influences of change in instructional effectiveness upon the affective characteristics of teachers. American Educational Research Journal, 21, 245-259.

Guskey, T. R. (1987). Context variables that affect measures of teacher efficacy. Journal of Educational Research, 81, 41-47.

Guskey, T. R. (1988). Teacher efficacy, self-concept, and attitudes toward the implementation of instructional innovation. Teaching and Teacher Education, 4, 63-69.

Hall, B., Burley, W., Villeme, M., \& Brockmeier, L. (1992, April). An attempt to explicate teacher efficacy beliefs among first year teachers. Paper presented at the annual meeting of the American Educational Research Association, San Francisco.

Hoy, W., \& Miskel, C. (2002). Educational administration: Theory, research, and practice (6th ed.). New York: McGraw-Hill.

Hoy, W., \& Woolfolk, A. (1993). Teachers' sense of efficacy and the organizational health of schools. Elementary School Journal, 93, 355372.

Ingersoll, R. (2001). Teacher turnover and teacher shortages: An organizational analysis. American Educational Research Journal, 38, 499534.

Kaplan, A., Gheen, M., \& Midgley, C. (2002). Classroom goal structure and student disruptive behavior. British Journal of Educational Psychology, 72, 191-211.

Kaplan, A., \& Maehr, M. (1999). Achievement goals and student wellbeing. Contemporary Educational Psychology, 24, 330-358.

Kaplan, A., Middleton, M., Urdan, T., \& Midgley, C. (2002). Achievement goals and goal structures. In C. Midgley (Ed.), Goals, goal structures, and patterns of adaptive learning (pp. 21-53). Mahwah, NJ: Erlbaum.

Kaplan, A., \& Midgley, C. (1999). The relationship between perceptions of the classroom goal structure and early adolescents' affect in school: The mediating role of coping strategies. Learning and Individual Differences, 11, 187-212.

Karabenick, S. (2004). Perceived achievement goal structure and college students help seeking. Journal of Educational Psychology, 96, 569-581.

Labone, E. (2004). Teacher efficacy: Maturing the construct through research in alternative programs. Teaching and Teacher Education, 20, 341-359.

Meece, J. (1991). The classroom context and students' motivational goals. In P. Pintrich \& M. Maehr (Eds.), Advances in motivation and achievement (pp. 261-285). Greenwich, CT: JAI Press.

Meece, J. (2002). Child and adolescent development for educators (2nd ed.). New York: McGraw-Hill.
Midgley, C., Anderman, E., \& Hicks, L. (1995). Differences between elementary and middle school teachers and students: A goal theory approach. Journal of Early Adolescence, 15, 90-113.

Midgley, C., Kaplan, A., Middleton, M., Maehr, M., Urdan, T., Anderman, L., et al. (1998). The development and validation of scales assessing students' achievement goal orientations. Contemporary Educational Psychology, 23, 113-131.

Midgley, C., Maehr, M., Hruda, L., Anderman, E., Anderman, L., Freeman, K., et al. (2000). Manual for the Patterns of Adaptive Learning Scales. Ann Arbor: University of Michigan.

Midgley, C., \& Urdan, T. (1995). Predictors of middle school students' use of self-handicapping strategies. Journal of Early Adolescence, 15, 389411.

Midgley, C., \& Urdan, T. (2001). Academic self-handicapping and achievement goals: A further examination. Contemporary Educational Psychology, 26, 61-75.

Murdock, T., Hale, N., \& Weber, M. (2001). Predictors of cheating among early adolescents: Academic and social motivations. Contemporary Educational Psychology, 26, 96-115.

Palmer, D., Stough, L., Burdenski, T., \& Gonzales, M. (2005). Identifying teacher expertise: An examination of researchers' decision making. Educational Psychologist, 40, 13-26.

Pintrich, P., \& Schunk, D. (2002). Motivation in education: Theory, research, and applications (2nd ed.). Englewood Cliffs, NJ: Prentice Hall.

Raudenbush, S., Rown, B., \& Cheong, Y. (1992). Contextual effects on the self-perceived efficacy of high school teachers. Sociology of Education, $65,150-167$.

Reese, W. (2005). America's public schools: From common school to "No child left behind." Baltimore, MD: Johns Hopkins University Press.

Richardson, V., \& Placier, P. (2001). Teacher change. In V. Richardson (Ed.), Handbook of research on teaching (4th ed., pp. 905-947). Washington, DC: American Educational Research Association.

Roeser, R., Midgley, C., \& Urdan, T. (1996). Perceptions of the school psychological environment and early adolescents' psychological and behavioral functioning in school: The mediating role of goals and belonging. Journal of Educational Psychology, 88, 408-422.

Rose, J. S., \& Medway, F. J. (1981). Measurement of teachers' beliefs in their control over student outcomes. Journal of Educational Research, 74, 185-190.

Ross, J. A. (1992). Teacher efficacy and the effect of coaching on student achievement. Canadian Journal of Education, 17, 51-65.

Ross, J. A., Cousins, J. B., \& Gadalla, T. (1996). Within-teacher predictors of teacher efficacy. Teaching and Teacher Education, 12, 385-400.

Rotter, J. B. (1966). Generalized expectancies for internal versus external control of reinforcement. Psychological Monographs, 80, 1-28.

Ryan, A., Gheen, M., \& Midgley, C. (1998). Why do some students avoid asking for help? An examination of the interplay among students' academic efficacy, teachers' social-emotional role, and the classroom goal structure. Journal of Educational Psychology, 90, 528-535.

Schumacker, R., \& Lomax, R. (2004). A beginner's guide to structural equation modeling. Mahwah, NJ: Erlbaum.

Stein, M. K., \& Wang, M. C. (1988). Teacher development and school improvement: The process of teacher change. Teaching and Teacher Education, 4, 171-187.

Tschannen-Moran, M., \& Woolfolk Hoy, A. (2001). Teacher efficacy: Capturing an elusive construct. Teaching and Teacher Education, 17, 783-805.

Tschannen-Moran, M., Woolfolk Hoy, A., \& Hoy, W. K. (1998). Teacher efficacy: Its meaning and measure. Review of Educational Research, 68, 202-248.

Turner, J., Meyer, D., Cox, K., Logan, C., DiCintio, M., \& Thomas, C. (2002). Creating contexts for involvement in mathematics. Journal of Educational Psychology, 90, 730-745. 
Urdan, T. (1997). Achievement goal theory: Past results, future directions. In M. Maehr \& P. Pintrich (Eds.), Advances in motivation and achievement (Vol. 10, pp. 99-141). Greenwich, CT: JAI Press.

Urdan, T. (2004). Predictors of academic self-handicapping and achievement: Examining achievement goals, classroom goal structures, and culture. Journal of Educational Psychology, 96, 251-264.

Urdan, T., Midgley, C., \& Anderman, E. (1998). The role of classroom goal structure in students' use of self-handicapping strategies. American Educational Research Journal, 35, 101-122.

Wentzel, K., \& Wigfield, A. (1998). Academic and social motivational influences on students' academic performance. Educational Psychology Review, 10, 155-175.

Wigfield, A. (1994). Expectancy-value theory of achievement motivation: A developmental perspective. Educational Psychology Review, 6, 4978 .

Wigfield, A., Eccles, J., \& Rodriquez, D. (1998). The development of children's motivation in school contexts. In P. D. Pearson \& A. IranNejad (Eds.), Review of research in education (Vol. 23, pp. 73-118). Washington, DC: American Educational Research Association.

Wolters, C. (2004). Advancing achievement goal theory: Using goal structures and goal orientations to predict students' motivation, cognition, and achievement. Journal of Educational Psychology, 96, 236-250.

Yost, R. (2002). "I think I can": Mentoring as a means of enhancing teacher efficacy. The Clearing House, 75, 195-197.

Young, A. (1997). "I think, therefore I'm motivated": The relations among cognitive strategy use, motivational orientation and classroom perceptions over time. Learning and Individual Differences, 9, 249-283.

Received January 19, 2006

Revision received October 5, 2006

Accepted October 12, 2006 